\title{
NESTING BEHAVIOR OF CRABRO ARGUSINUS AND C. HILARIS (HYMENOPTERA: SPHECIDAE)
}

\author{
By Robert W. Matthews, Allan Hook ${ }^{1}$ AND \\ JOAN W. KRISPYN \\ Department of Entomology \\ University of Georgia \\ Athens, Georgia 30602
}

\section{INTRODUCTION}

The Crabroninae comprise over 1200 species of small to large solitary wasps which exhibit considerable behavioral diversity (Bohart \& Menke 1976). The Holarctic genus Crabro includes 85 species with 47 found in the Nearctic region (Bohart 1976). Males of about $3 / 4$ of these species possess a rather bizarre tibial "shield" thought to function in courtship, a hypothesis which awaits confirmation. Nesting information is recorded for members of 6 of the 10 species groups recognized by Bohart, but few detailed studies have been made. Kurczewski and Acciavatti (1968) reviewed the biology of the Nearctic species listing a number of behavioral generalizations applicable to Crabro. All known species are relatively uniform in their nesting behavior, compared to the diversity of behaviors found in other sphecid genera of comparable size. Evans et al. (1979) have recently extended our knowledge of Nearctic Crabro with observations on 7 species.

The 2 species reported here, $C$. argusinus Packard and C. hilaris F. Smith, are "typical" members of the genus although each belongs to a different species group. This is the first record of nesting for $C$. hilaris; C. argusinus was studied briefly by Evans (1960) and again in 1970 (Evans et al. 1979) in New York.

With the exception of one population briefly observed on the mainland $11 \mathrm{mi} \mathrm{E}$ of Midway, Georgia, all observations were made on St. Catherine's Island, GA, a coastal island situated about 30 miles south of Savannah. The study spanned three seasons 19761978. Principal island study sites are located in Fig. 1.

\footnotetext{
'Present address: Department of Zoology and Entomology, Colorado State University, Ft. Collins, CO 80523

Manuscript received by the editor November 13, 1979
} 


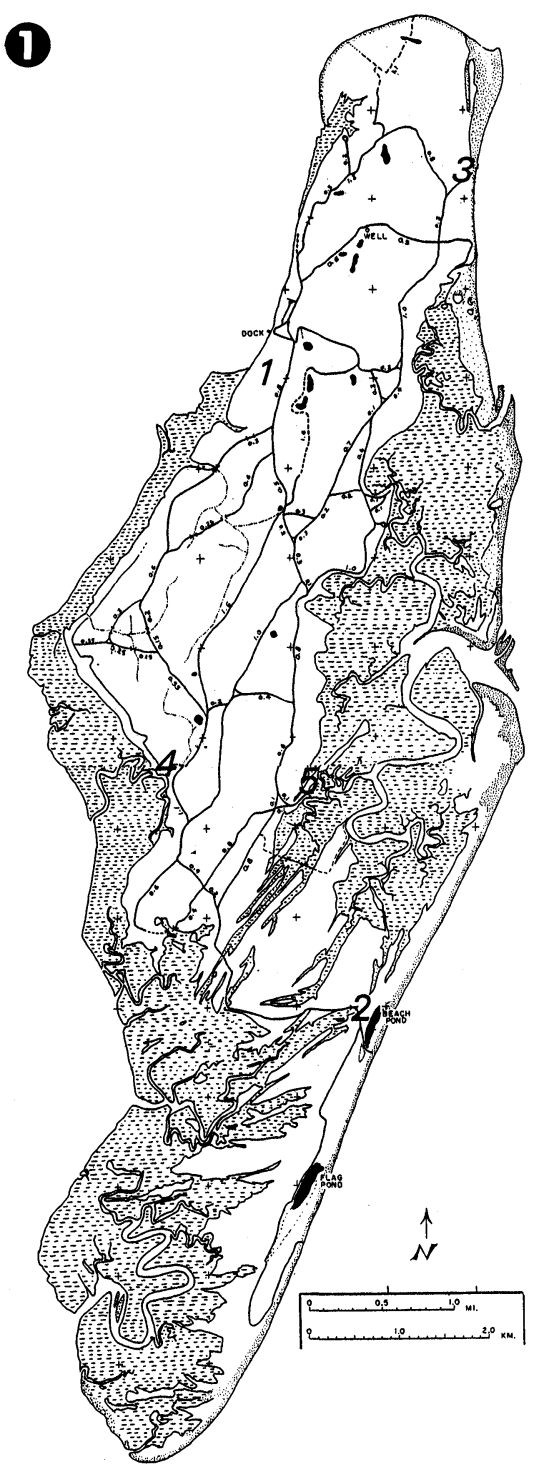

Figure 1. St. Catherine's Island, Georgia, with study sites where populations of Crabro hilaris (sites 1 and 2) and C. argusinus (sites 3, 4 and 5) nested. 


\section{Crabro hilaris F. Smith}

This previously unstudied species was discovered on October 29-30, 1977 when several nests were found at two inland localities. A check of the same localities on October 5, 1978 failed to turn up any $C$. hilaris, which suggests that this species is a late season nester. Intensive collecting on the island throughout the summers of 1977 and 1978 and the early spring of 1978 also failed to turn up any specimens suggesting that the species is univoltine.

The majority of our observations were made along a plowed strip of sandy loam soil extending across a grassy clearing of about 100 m. The habitat (Fig. 2) had been created earlier in 1977 (late July) as a firebreak approximately $1 \mathrm{~m}$ wide. We counted about 30 active nests along this firebreak. Another smaller aggregation of about 15 nests was found in sandy soil adjacent to a road several $\mathrm{km}$ away.

Eight nests were successfully excavated. These contained from 1-5 cells per nest. Burrows descended nearly vertically (Fig. 3); cells were situated $5-8 \mathrm{~cm}$ to the side of the main burrow and averaged 28 $\mathrm{cm}$ deep (ranges $25-38 \mathrm{~cm} ; \mathrm{n}=14$ ). Two measured cells were $7.5 \times 14$ $\mathrm{mm}$ and $6 \times 20 \mathrm{~mm}$. Cells contained an average of 9 flies (range $4-14 ; n=13)$. Prey were identified as follows:

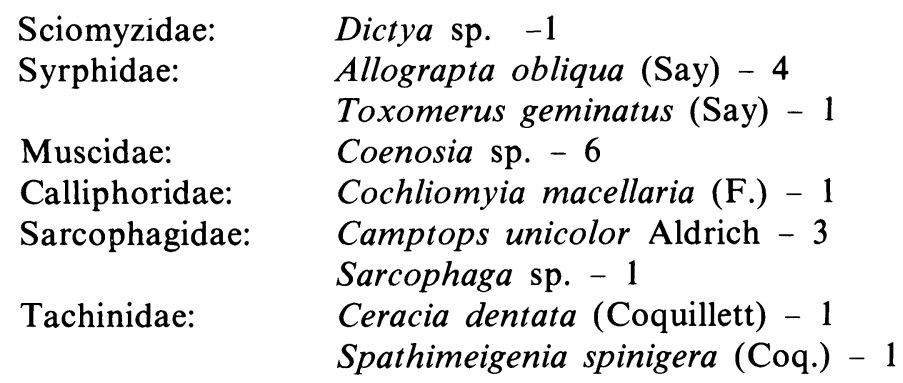

One female was observed to initiate a new nest only $1 \mathrm{~cm}$ away from her previous nest. Soil was loosened with the mandibles and forelegs and pushed backwards with the assistance of the mid and sometimes the hind legs. As she digs the female slowly rotates through $360^{\circ}$ while penetrating the surface and she was very soon completely hidden by the accumulating mound. Nest entrances were surrounded by a conspicuous tumulus of unleveled soil averaging about $5 \mathrm{~cm}$ diam. Burrow diameter was $4-5 \mathrm{~mm}$. 


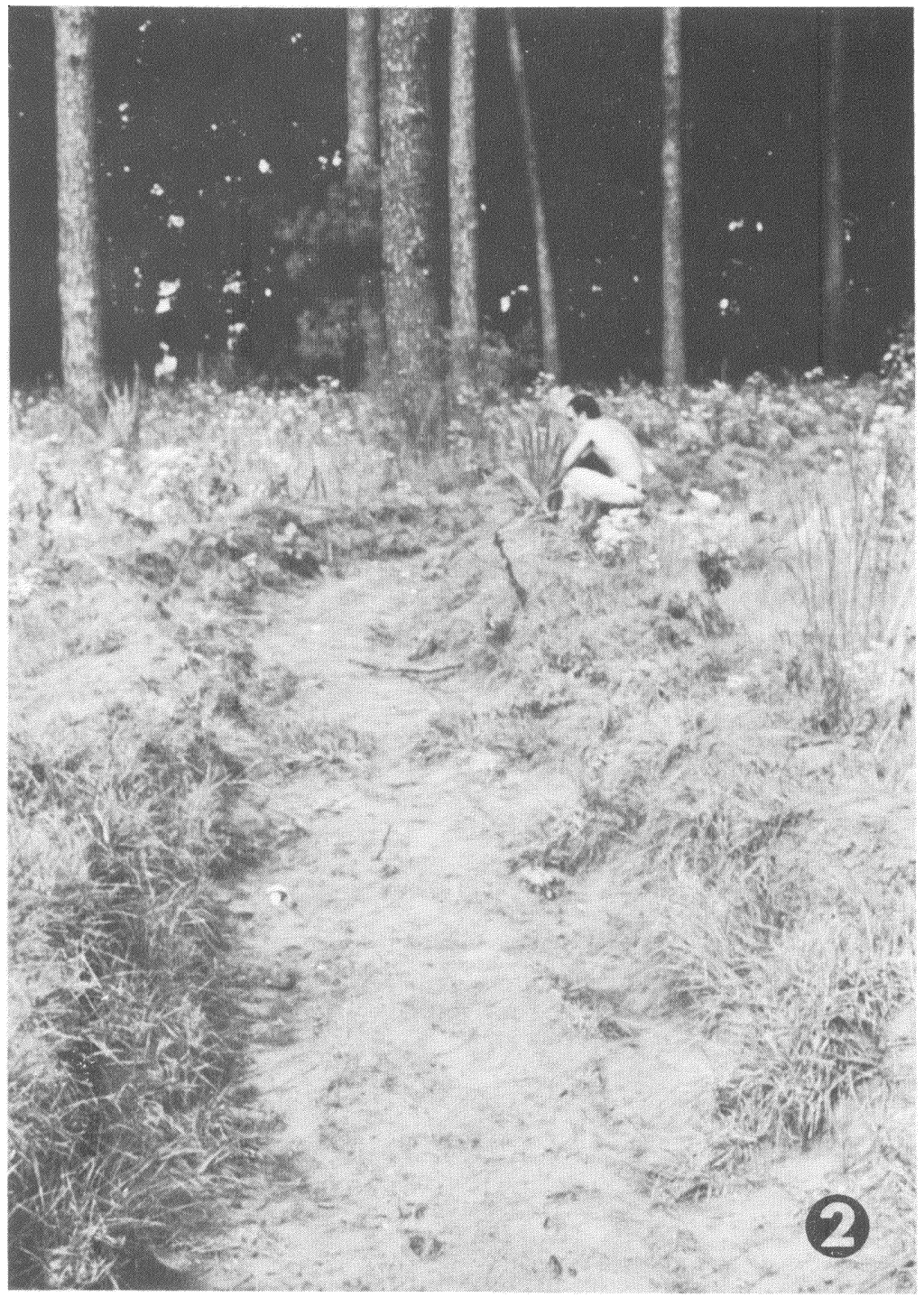

Figure 2. Plowed "firebreak" where Crabro hilaris nested in 1977 (site 1 in Fig. 1). 
Nest entrances are left open during periods of active provisioning and closed at night. Prey-laden females typically approach from about $2 / 3 \mathrm{~m}$ above their entrance and then slowly descend nearly vertically into the open entrance. Flight is silent and prey is held venter up by the middle legs. Provisioning appeared to occur throughout the day. Departing females were often observed to rest motionless with their head blocking the nest entrance for several minutes before departure.

Parasitism by miltogrammine flies was $26.7 \%$ overall with maggot-infested cells found in nests from both aggregations. As many as 6 maggots were found in a single cell. Those reared were identified as Senotainia sp. or S. trilineata (Wulp).

Three adult wasps were successfully reared from cocoons maintained at room temperature. A male emerged the following February and a female emerged in mid-April, followed by another in May.

Miller and Kurczewski (1976) have made observations on two other members of the hilaris species group.

\section{Crabro argusinus Packard}

This species was clearly bivoltine, having both a spring and a fall generation on St. Catherine's Island. In late April, 1978 it was without question the "dominant" species of solitary wasp, occurring ubiquitously over the island. We studied it principally at 3 localities (Fig 1). One was at the northern end of the island where it nested in steep eroding sand cliffs and blowouts adjacent to the ocean (Fig. 4) that we termed the "north beach site". Another was termed the Wamassee Creek site and was located on the western edge of the island. Here the wasps nested sparsely over a large area of sand bank exposed by the meandering Wamassee Creek. The third study site was called the "boiler site" because of its proximity to an abandoned oyster boiler (Fig. 5). This locality was considerably more protected than the north beach area and the Wamassee Creek site was surounded on three sides by salt marsh. In contrast to the nearly vertical nesting surfaces at the other sites, nests at the boiler site were constructed in flat, more or less open sandy soil having a surface of crushed oyster shells. High tide level came to the edge of the nest area with the highest of the spring tides occasionally briefly inundating the entire nest site. The nesting population at the boiler site was rather localized, consisting of about 50 nests concentrated in an area of about $2 \times 8 \mathrm{~m}$. Nests at the north beach and Wamassee 


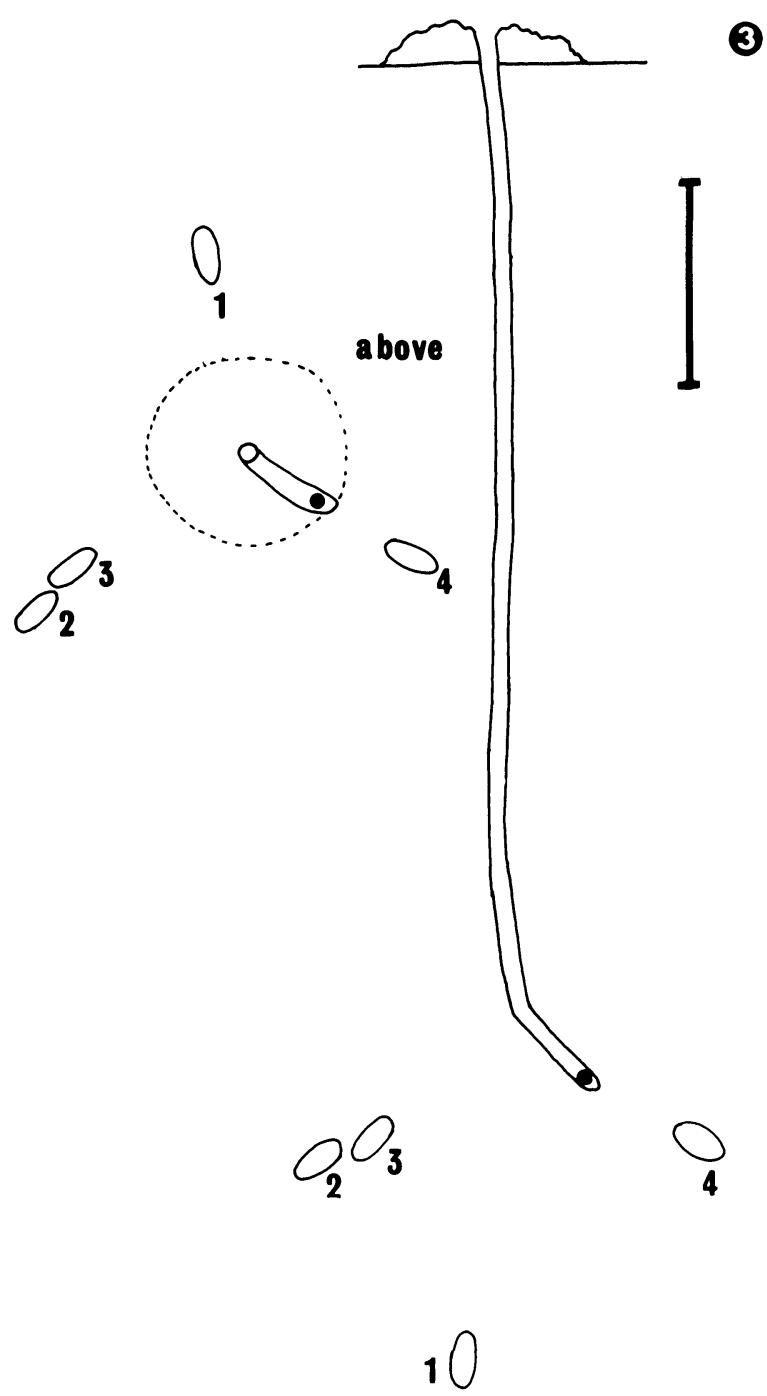

Figure 3. Profile and top view of a typical nest of Crabro hilaris. Black dot indicates burrow storage site of flies prior to placement in cell. Cells are numbered according to apparent order of construction based upon larval development. Scale bar is $5 \mathrm{~cm}$. 


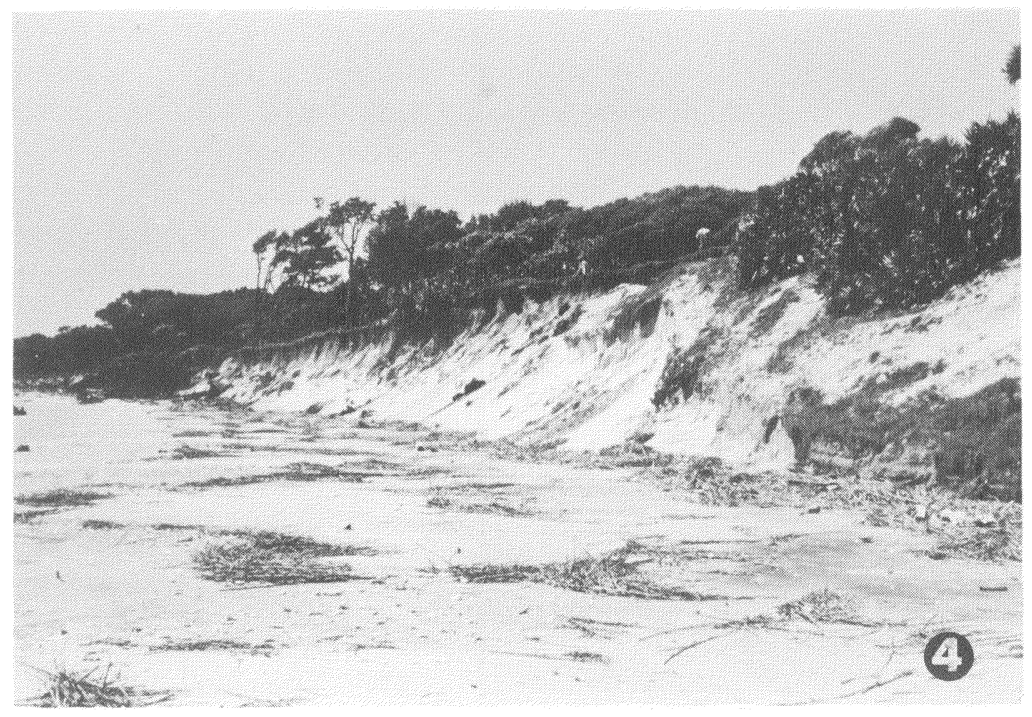

Figure 4. "Clitf" at the north beach site (site 3 in Fig. 1), containing numerous nests of Crabro argusinus scattered throughout the middle portions of the cliff. Females hunted prey along the high tide line among the washed-up debris (mostly Spartina reeds).

Creek sites were scattered over a much larger area, with over 100 nests estimated to be active in each area. In early October, 1978 we also excavated a few nests from a sandy road which led to the boiler site about $100 \mathrm{~m}$ away. Evidently we were too early for most of the fall nesting season, since, despite extensive searching, no C. argusinus were nesting at the other sites at this date and all nests found on the road were fresh and the population seemed to be greatly increased on the last day of our visit.

Table 1 summarizes data obtained from 31 nest excavations of this species according to date and locality. At all sites burrows entered the soil obliquely at roughly a $60^{\circ}$ angle to the surface and contained from 1-7 cells situated 3-5 cm from the sides of the tunnel end (Figs. 6-7). Prey accumulate in the bottom of the burrow and are later transferred to the cell. Eggs are attached to the throat of one of the largest flies situated venter up, head in-first, farthest into the cell. Burrow diameter was 4-5 $\mathrm{mm}$ and on level soil a distinct unleveled tunnel of soil accumulated around the entrance. The 16 cells measured fell into 2 clusters, smaller cells $5 \times 10 \mathrm{~mm}-6 \times 14 \mathrm{~mm}$ and larger cells $7 \times 15 \mathrm{~mm}-8 \times 17 \mathrm{~mm}$. 
Considering the 2 main study localities (north beach and boiler site), comparisons of the different populations from the same season as well as comparisons of populations from different seasons at the same site reveal some rather striking differences (Table 1). Fall populations at the north beach site constructed nests with cell depths averaging 16.1 to $17.0 \mathrm{~cm}$ (2 successive seasons). Cells contained an average of 11.2 to 14.6 prey ( 2 successive seasons). Spring populations nesting at the same site constructed significantly deeper burrows, with cell depths averaging $28.9 \mathrm{~cm}$ and provisioned with a much larger number of flies $(\overline{\mathrm{x}}=30.9 /$ cell $)$.

Comparing populations of the two main localities at the same season (spring 1978) also revealed important differences. Spring nests at the boiler site were significantly shallower and cells were provisioned with fewer flies per cell (Table 1). Prey preferences also differed somewhat, possibly reflecting differences in hunting habitats. The north beach population lacked ready access to salt marsh and appeared to hunt mainly along the beach. Even so, 12 of 32 prey species were represented in cells at both sites (Table 2). Ephydridae and Dolichopodidae were preferred prey at both sites.

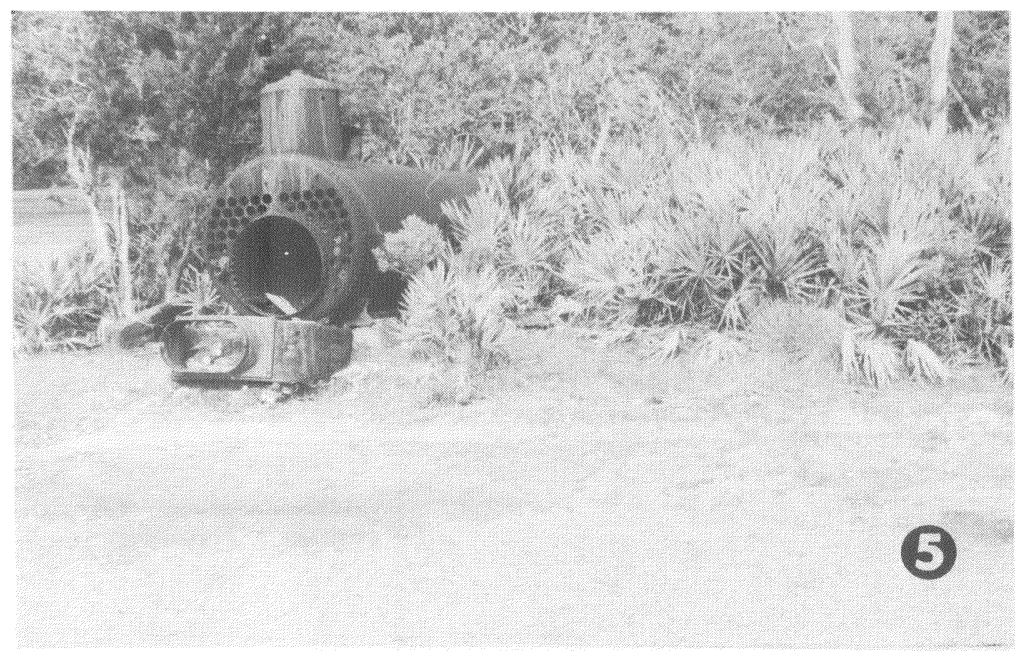

Figure 5. Boiler site (site 5 in Fig. 1); Crabro argusinus nested in the flat area in the foreground. Back Creek runs adjacent to this site on the left, and an extensive area of salt marsh extends behind the viewer. High tides occasionally barely covered the nest area. 


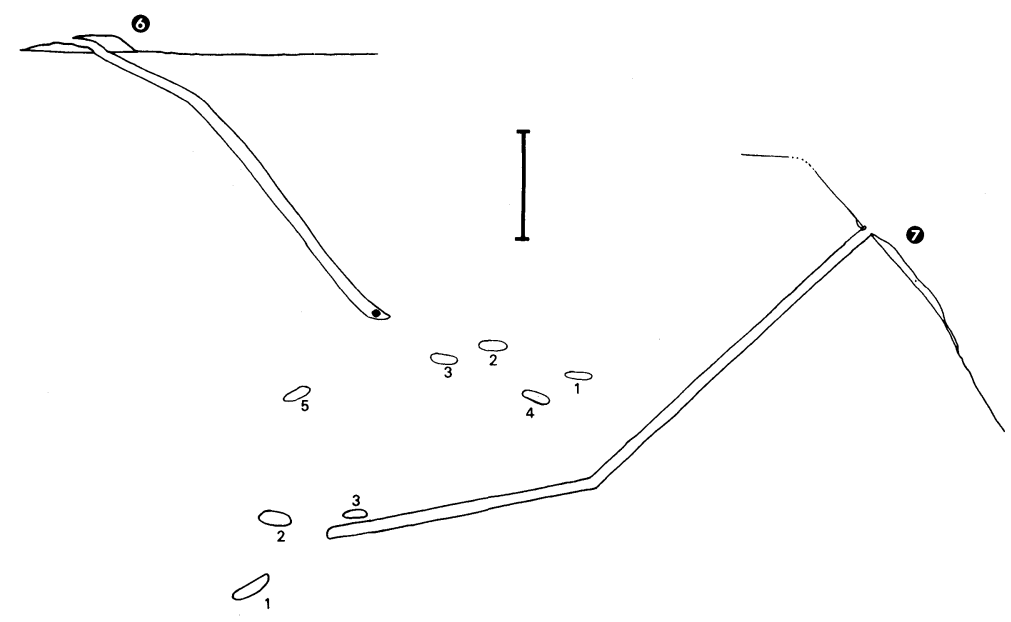

Figures 6-7. Profiles of typical Crabro argusinus spring nests from (6) the boiler site, and (7) the north beach site. Cells are numbered according to apparent order of provisioning based upon larval development. Black dot indicates point where prey flies were stored in burrow prior to transfer to a cell. Scale bar is $5 \mathrm{~cm}$.

Hunting behavior and prey capture was observed on several occasions at the north beach site. Females flew slowly into the wind along the high tide line where salt marsh reeds and other debris had accumulated along the base of the cliffs. Prey appeared to be detected visually as they rested on the white sand as wasps were frequently seen to dart at small dark pebbles of the same size as the flies. Upon spying a potential prey item the wasp hovered momentarily about $10 \mathrm{~cm}$ downwind of it and 6-8 $\mathrm{cm}$ above the substrate, then suddenly it darted forward very quickly and pounced upon the prey in an attack aptly described as "hit and run". It was possible to walk alongside of individual females for several meters as they flew slowly along pouncing on one object after another until they were finally successful in capturing a prey item. In contrast to the majority of other species of Crabro, C. argusinus prey were clearly paralyzed and not necessarily killed.

In addition to the physical differences between these two study localities, differences in the abundance of parasites were also striking. At the more localized and protected boiler site miltogrammine flies were excessively common and reflecting this, the incidence of 


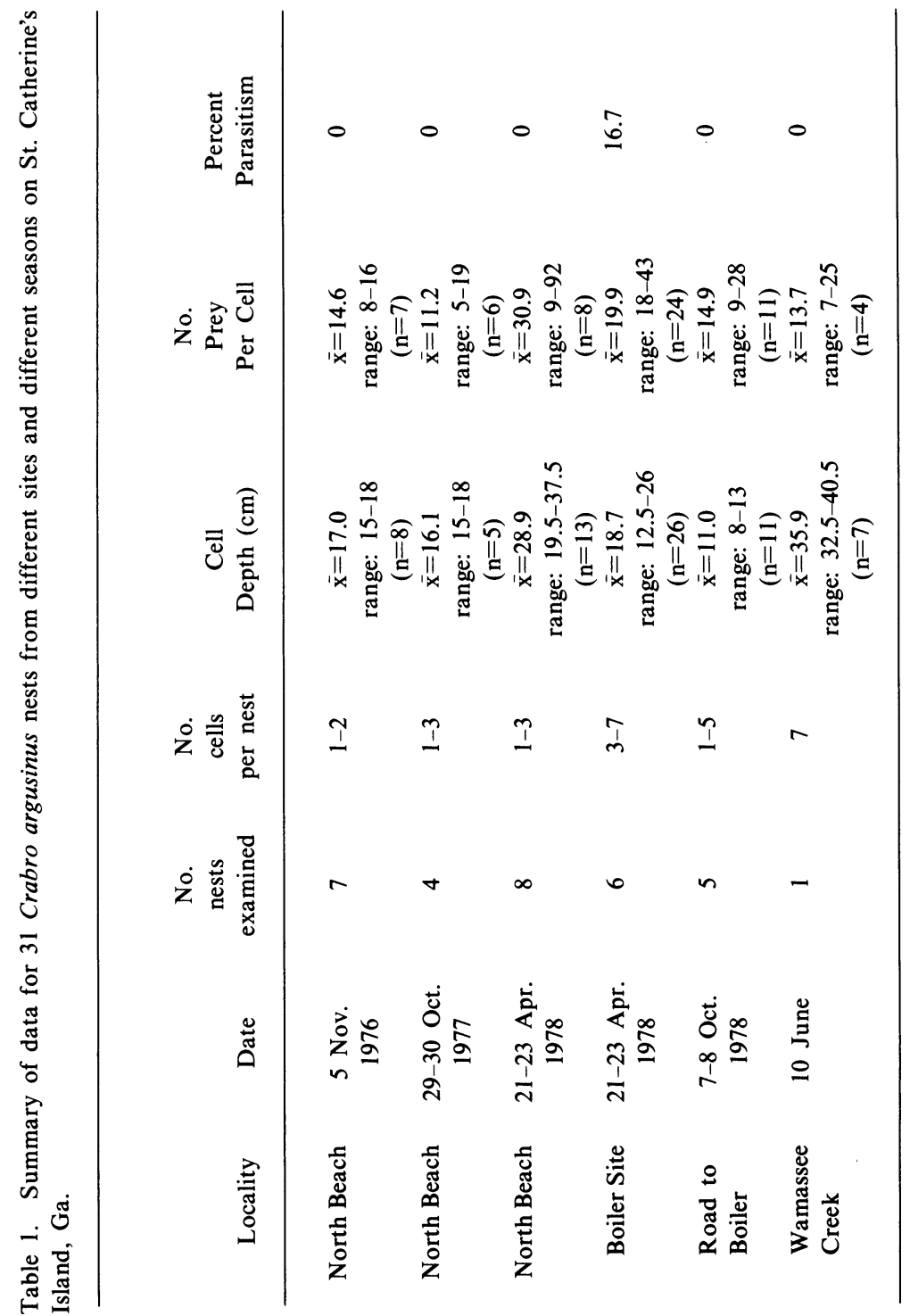


parasitized cells was $16.7 \%$ in April, 1978. Miltogrammine flies collected or reared from the boiler site belonged to two genera, Senotainia spp. and Sphenometopa sp. At north beach no miltogrammine flies were seen and no parasitized cells were found. Possibly the strong and persistent winds blowing along the north beach cliffs dispersed the parasites. Also, it may simply be that it was less "profitable" for the flies to invest time and energy battling the winds to locate the widely dispersed nests. At the road site in October, 1978, parasite flies were common, but no parasitized cells were found. Two flies collected here were Senotainia trilineata (Wulp) and Sphenometopa tergata (Coquillett).

Perhaps correlated with the presence or absence of parasites, the behavior of provisioning females differed strikingly. Prey-laden females returning to open nests at the boiler site made a distinctive approach flight in which they would approach the nest entrance and then slowly drift backwards away from the nest. Some females were observed to retreat as much as $3 \mathrm{~m}$ in a rather pulsating flight about $6-10 \mathrm{~cm}$ above the substrate. This conspicuous flight behavior usually attracted 1 to several miltogrammine flies who followed in close synchrony with the movement pattern of their potential host (hence the very apt common name $=$ satellite flies). Having lured the parasites off some distance, the female suddenly and unpredictably zoomed forward in a "bee line" plunging headlong into her open entrance and leaving the flies behind, somewhat disoriented. The same behavior was observed on the mainland site, a flat expanse of sandy soil constituting a turnaround area at the end of a dirt road. Several miltogrammine flies were sighted at this area. Comparable behavior was never seen in females nesting at north beach or Wamassee Creek, and may therefore represent a response to increased parasite pressure at the boiler and mainland sites. Evans (1960) records the same behavior for this species when pursued by miltogrammines. Closely similar anti-parasite provisioning behavior has also been described for an unrelated sphecid, Philanthus crabroniformis F. Smith by Alcock (1974).

On at least one occasion a Senotainia was observed to follow a female wasp into her burrow. Nests were typically left open during provisioning, but at least two females made weak temporary outer closures between provisioning trips and "crashed" directly into their nests upon returning. This behavior may have been a response to parasite pressure. Several parasitized cells contained more than one 


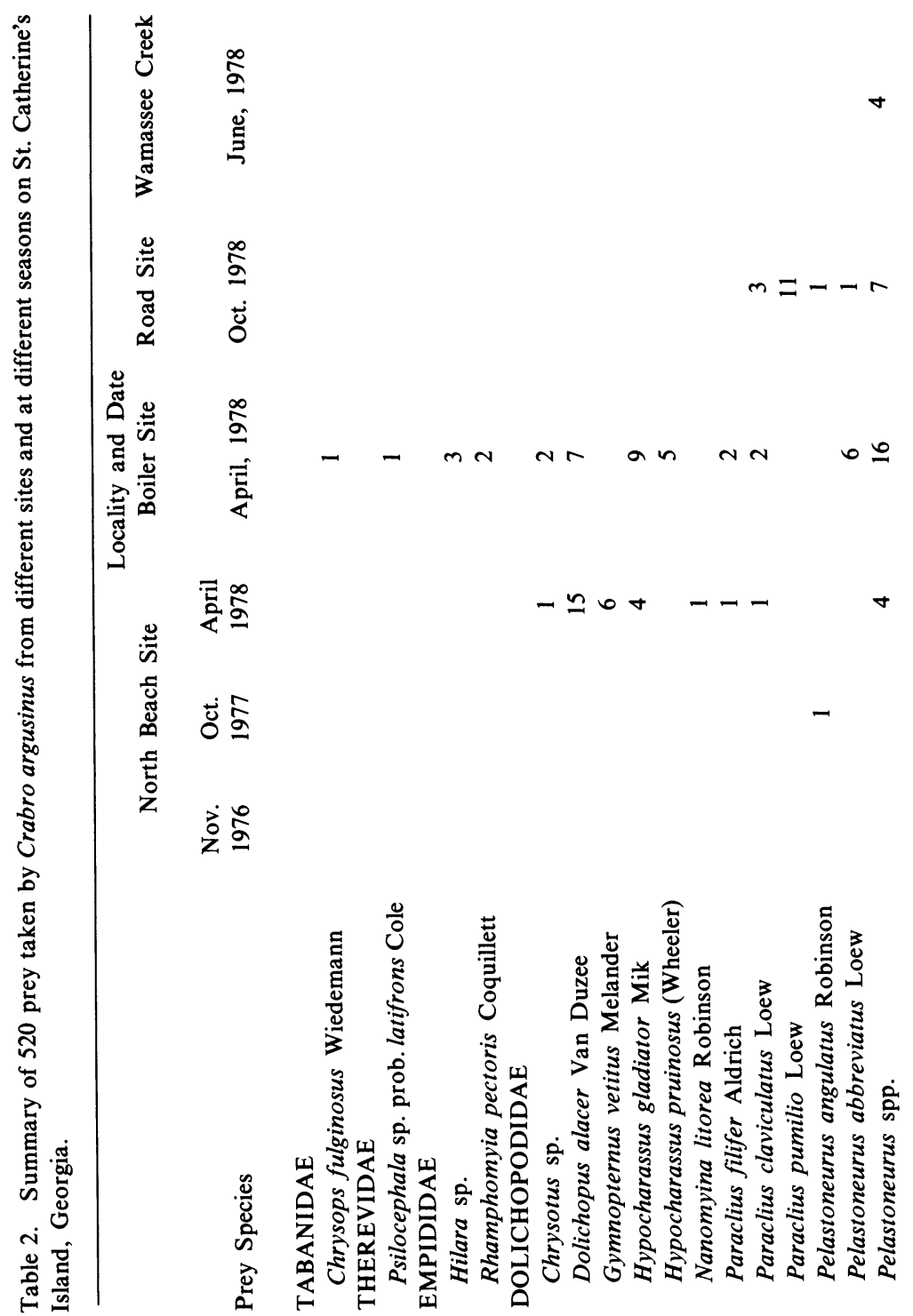



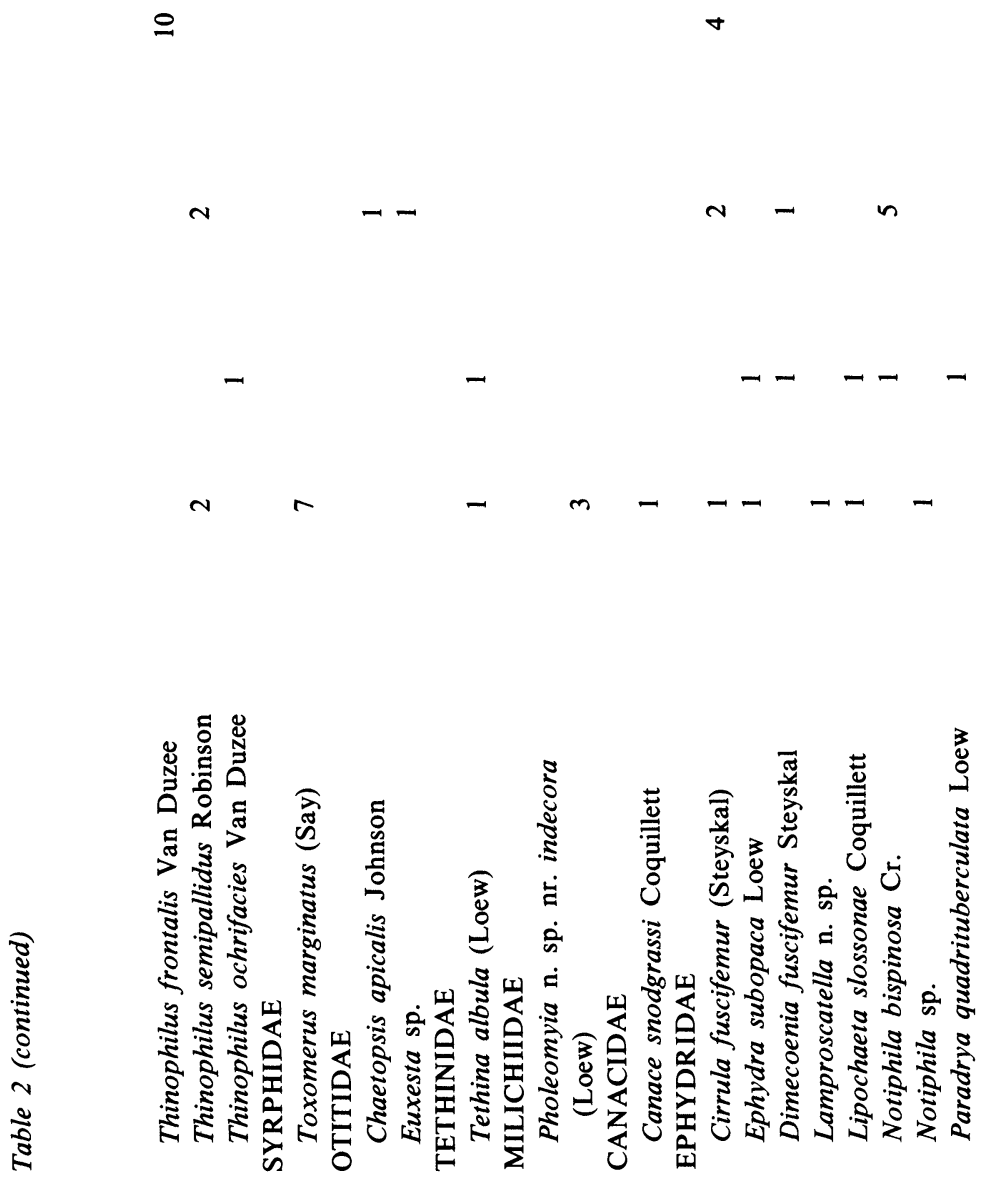


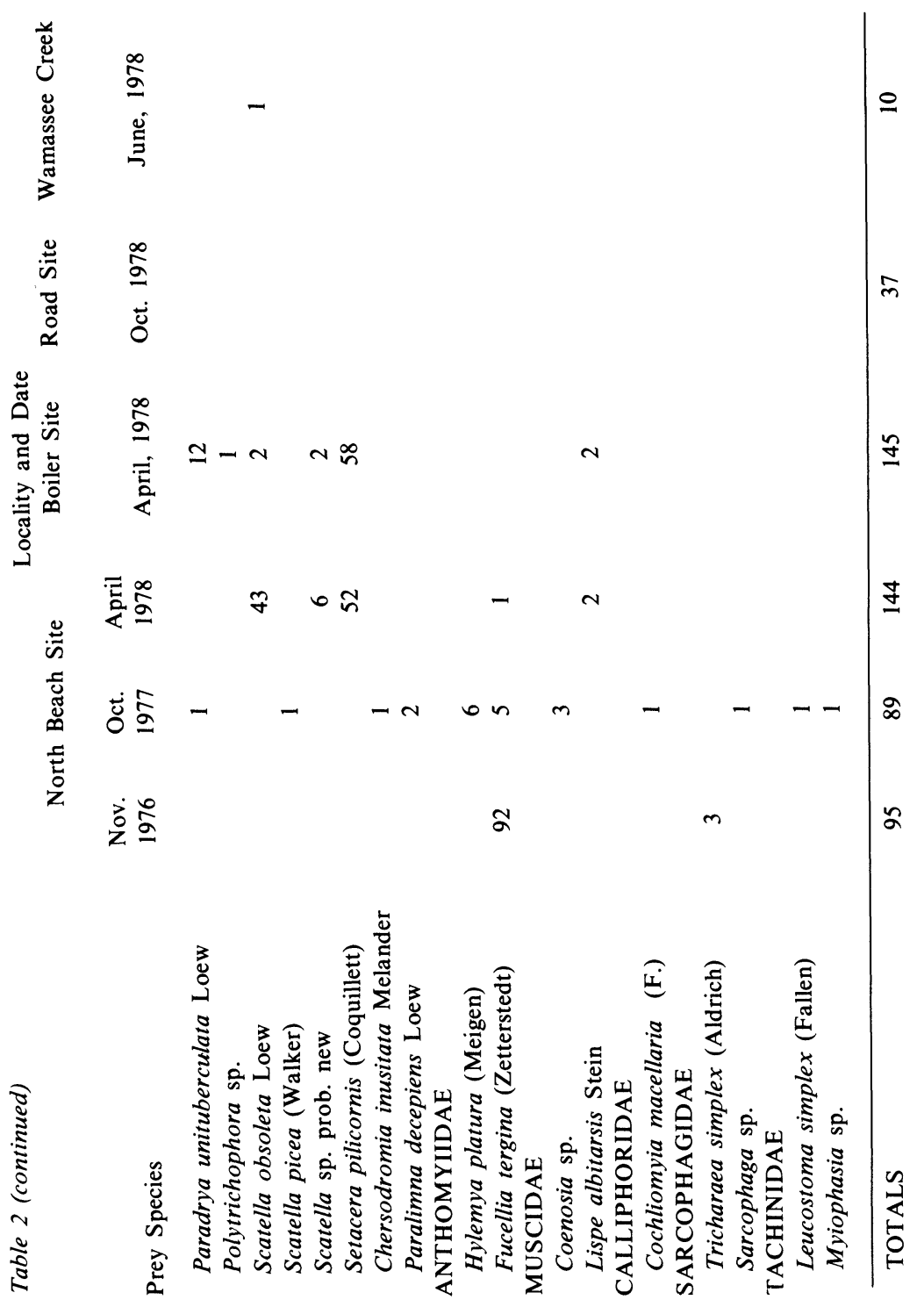


maggot. Total development time for one of the Sphenometopa reared was 22 days. One cocoon excavated during April, 1978 was found to contain unidentified nematode worms.

On sunny warm days females appeared to construct 2 cells per day. A period of intense provisioning activity occurred in the late mornings with a majority of nests closed from within during the middle part of the day. Late in the afternoon there would again be a period of intense provisioning activity. Observations of individual females revealed that flies were brought in at the rate of 1 fly every 3 to 4 min during peak activity. A summary of all prey is given in Table 2, and includes over 50 species from 15 families. Brine flies (Ephydridae) and Dolichopodidae are the preferred prey, but in the late fall the anthomyiid Fucellia tergina constituted the primary prey at North Beach. Evans (1960) recorded 15 species of prey from his New York study which also were predominantly Dolichopodidae and Ephydridae.

Males were seldom seen. However, on October 7, 1978, 2 males were observed investigating freshly dug burrows at the road site adjacent to the boiler site. This date was clearly early in the fall nesting season, for no nests had been initiated at the boiler site nearby nor were any found at north beach, and during the subsequent 2 days several new nests were initiated at this site. Another male was taken on November 4, 1976, dug from a "sleeping" burrow $5 \mathrm{~cm}$ deep found among an aggregation of nests in a blowout area at north beach. On May 11, 19782 males were observed searching about nest entrances in a small sand pile at the mainland site.

Males of about 3/4 of Nearctic Crabro possess an enlarged shieldlike projection on the front tibia. Bohart (1976) suggested a clasping role for the male tibial shield, but pointed out that "this does not explain the great variety and ornamentation of the shield according to species" which may also serve a "display function" in courtship. In an attempt to learn the possible role of the male tibial shield, on 28 May 1978 two reared males were placed in a plexiglass observation cage $(76 \mathrm{~cm} \times 60 \mathrm{~cm} \times 36 \mathrm{~cm})$ with a reared female known to be unmated. One male repeatedly hovered $3-5 \mathrm{~cm}$ above the female as she crawled up the container sides and pounced on her several times. Males are not very discriminating; it was not unusual for one male to hover and pounce on the other several times before searching elsewhere. However, several mounting attempts were observed in which the male placed his shields over the eyes of the female, but the 
female was apparently not receptive and no copulations were observed. Evans (pers. comm.) suggests that Crabro females recognize their species specific pattern when their eyes are covered by these distinctively marked male tibial shields. Light passing through such thin, partially transparent shield cuticle could transmit a characteristic pattern which might alter female receptivity.

Several cocoons of $C$. argusinus were obtained during the course of this work and one of them is shown in Fig. 8. Developmental data were obtained for a few cells transferred to rearing tins during the spring of 1978. One egg laid April 22 developed to mature larva which spun its cocoon on April 26-27 and emerged as an adult on May 20. It seems likely that there is at least a partial second generation in the spring. During our visit in late April nesting seemed to be at a peak at all localities. The boiler site colony was still active on 12 May when we returned, but activity ceased about 20 May and Oxybelus sericus Robertson became the dominant species at that site. The last nest was dug on 10 June 1978 at the Wamassee Creek site where only a few active nests remained at that date.

Searching females were repeatedly observed to dart at the sides of depressions in the substrate. At the road site females showed a decided bias for nest sites situated in depressions as compared to surrounding flat sand. For example, a horse hoof print had 4 closely spaced nests initiated in the angle formed by the sides and base of the print within $24 \mathrm{hr}$. Such a close spacing of nests is unusual. Evans (1960) never found active nests closer than half a meter. His study site was an erosional bank of a draw, most similar to our
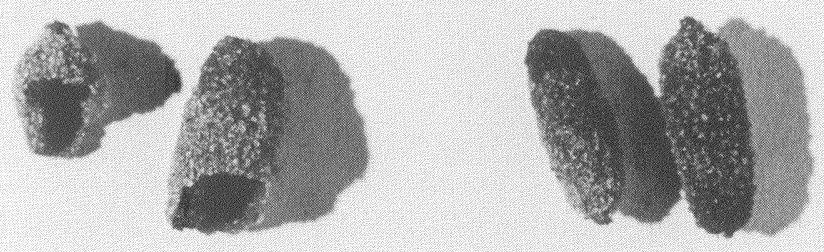

8

Figure 8. Cocoons of Crabro argusinus. Length of right cocoon is $7 \mathrm{~mm}$. 
north beach site where nests were also typically widely spaced. Since time did not permit following the above 4 nests to completion, all were excavated late in the day that they were initiated. In every case the burrow excavation was still incomplete and no prey had yet been stored. This indicates that $C$. argusinus requires at least one day to excavate the main tunnel.

\section{Discussion}

Like all known Crabro, $C$. hilaris and $C$. argusinus nest in sandy soil and prey upon a variety of Diptera. $C$. hilaris prefers stockierbodied flies, primarily muscoids whereas argusinus utilizes a wide diversity of prey, but prefers ephydrids and dolichopodids. C. hilaris inhabits inland protected locations in flat soil, whereas $C$. argusinus characteristically nests in close association with water and prefers to nest in slopes or in the sides and "corners" of depressions in relatively flat open sand.

Striking differences in the behavior and nest parameters of the two populations of $C$. argusinus studied at the same season may be due to differences in both biotic factors (available prey and parasite pressure) and physical factors (erosion, wind, etc.). The larger number of prey stocked per cell at the north beach site may in part reflect the absence of parasites and in part a preference for smaller sized prey. It may also reflect different hunting habitats, beach versus salt marsh; larger flies may be more accessible in the marsh. At the boiler site, the presence of strong parasite pressure may have caused wasps to finish provisioning sooner. The greater depth of cells at north beach possibly reflects the relative instability of that habitat where erosion continually whittled away at the cliff bank. In contrast, the boiler site has probably changed very little in the many years since the boiler was abandoned. However, reasons for the much greater depth of spring nests as compared to that of fall nests at north beach are unknown. The road site where the shallowest nests were found was very compacted sand with innumerable roots which caused nests at this site to be very contorted. It may be that digging behavior is genetically controlled and shut off after a predetermined amount of energy is expended which would vary between localities and seasons.

In overall biology these two species fit the typical Crabro pattern on all traits enumerated by Kurczewski and Acciavatti (1968) and summarized by Bohart and Menke (1976). Nevertheless, variation 
between populations nesting in different habitats at the same season and between populations nesting at the same sites at different seasons demonstrates a rather larger amount of behavioral plasticity than might have otherwise been anticipated.

\section{ACKNOWLEDGEMENTS}

We would like to dedicate this paper to Professor Howard E. Evans on the occasion of his 60th birthday. This paper is a part of a comparative study of sand wasp behavior undertaken on St. Catherine's Island with the support of the Edward John Noble Foundation in cooperation with the American Museum of Natural History. For prey and parasite identifications we are indebted to the following specialists: R. J. Gagne (Muscidae, Calliphoridae and Sarcophagidae); L. Knutson (Sciomyzidae and Empididae); W. N. Mathis (Ephydridae and Canacidae); C. W. Sabrosky (Milichiidae and Tachinidae); G. Steyskal (Anthomyiidae, Tethinidae and Otitidae); F. C. Thompson (Tabanidae, Syrphidae and Dolichopodidae); and W. W. Wirth (Therevidae). R. M. Bohart confirmed the identities of the Crabro. Voucher specimens are deposited in the University of Georgia P. W. Fattig Museum.

\section{REFERENCES}

Alcock, J.

1974. The behaviour of Philanthus crabroniformis (Hymenoptera: Sphecidae). J. Zool. (London) 173: 233-246.

BOHART, R. M.

1976. A review of the Nearctic species of Crabro (Hymenoptera: Sphecidae). Trans. Amer. Ent. Soc. 102: 229-287.

Bohart, R. M. AND A. S. MenKe.

1976. Sphecid Wasps of the World. University of California Press, Berkeley, $695 \mathrm{pp}$.

Evans, H. E.

1960. Observations on the nesting behavior of three species of the genus $\mathrm{Cra}$ bro (Hymenoptera: Sphecidae) J. N. Y. Ent. Soc. 68: 123-134.

Evans, H. E., F. E. Kurczewski and J. Alcock.

1979. Observations on the nesting behavior of seven species of Crabro (Hymenoptera: Sphecidae). (in preparation)

Kurczewski, F. E. and R. E. Acciavatti.

1968. A review of the nesting behavior of the Nearctic species of Crabro, including observations on $C$. advenus and C. latipes (Hymenoptera: Sphecidae). J. N. Y. Ent. Soc. 77: 152-170.

Miller, R. C. AND F. E. KuRCZewsKi.

1976. Comparative nesting behaviors of Crabro rufibasis and Crabro arcadiensis (Hymenoptera: Sphecidae: Crabroninae). Florida Ent. 59: 267285. 

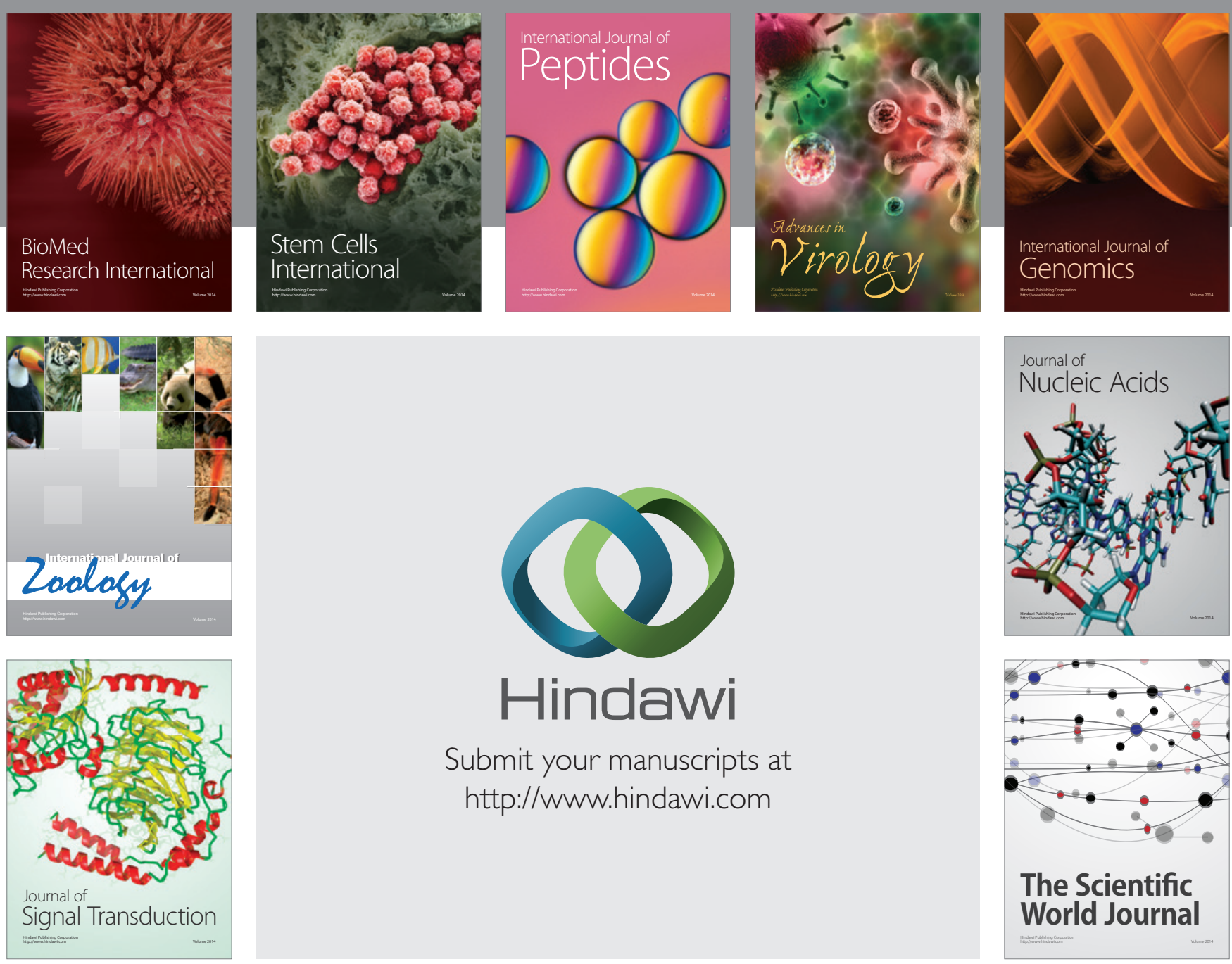

Submit your manuscripts at

http://www.hindawi.com
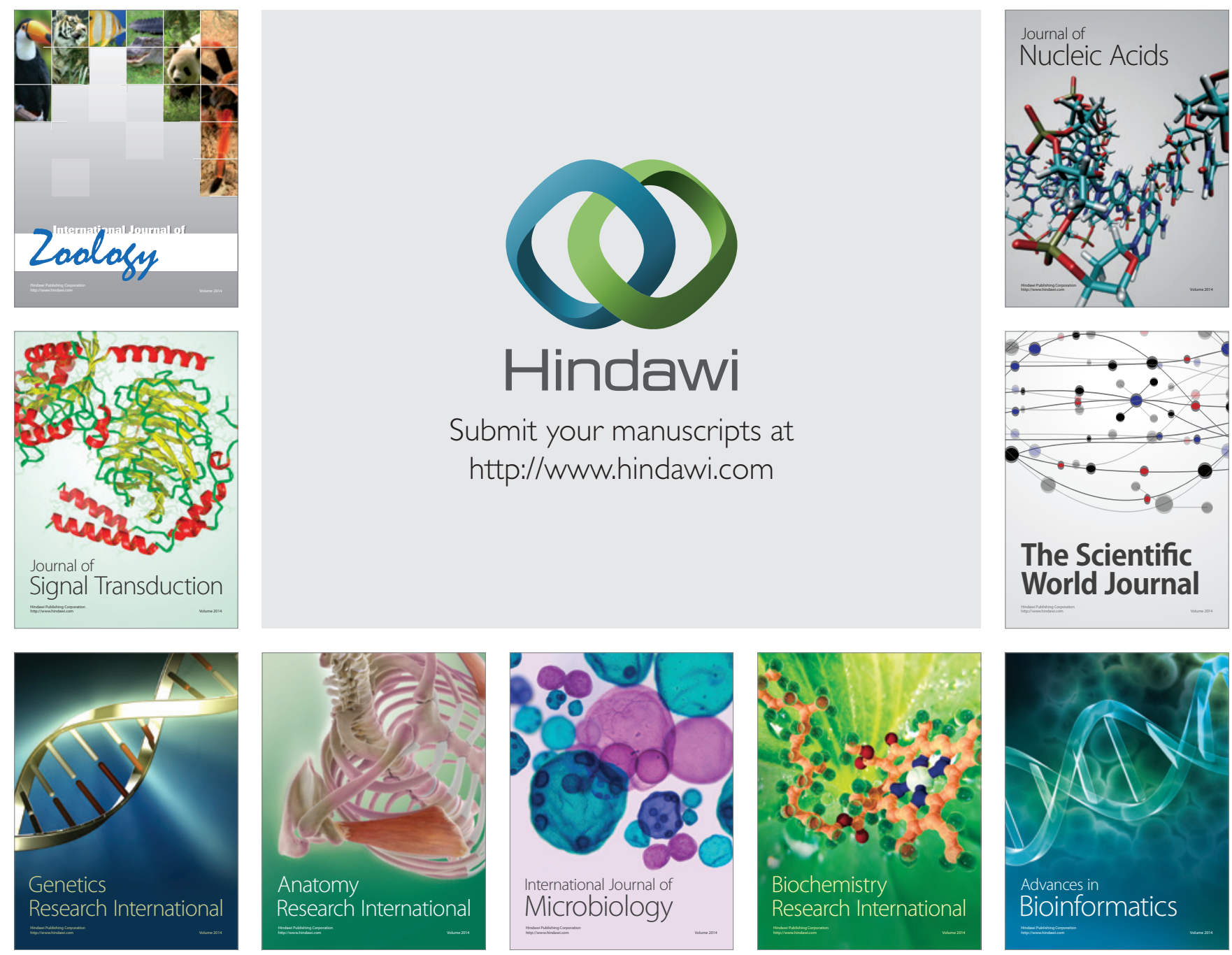

The Scientific World Journal
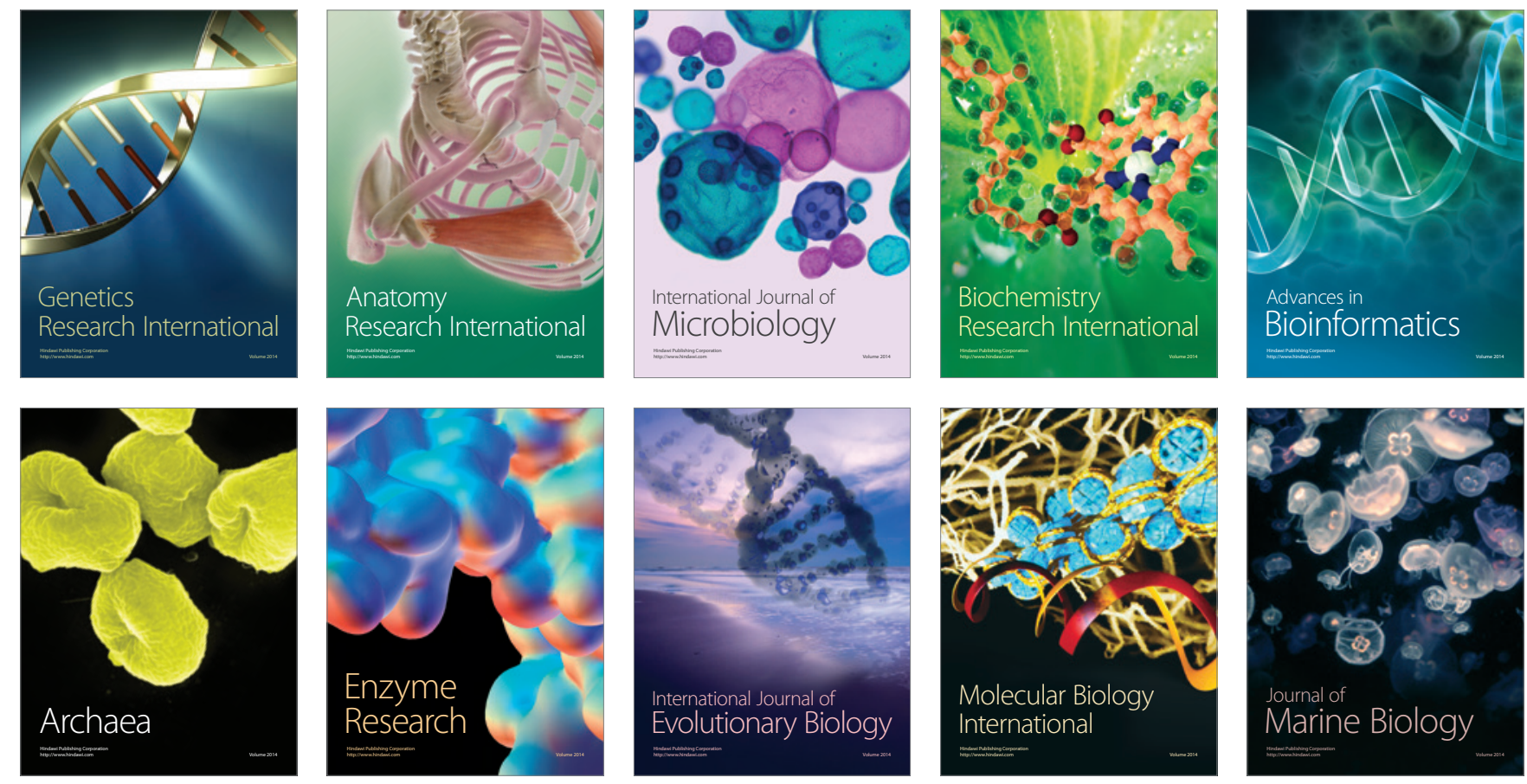